\title{
Genetic variants of IncRNA HOTAIR and risk of epithelial ovarian cancer among Chinese women
}

\author{
Haijing Wu ${ }^{1}$, Xiaofei Shang ${ }^{1}$, Yu Shi ${ }^{1}$, Zhirong Yang ${ }^{1}$, Jun Zhao ${ }^{1}$, Min Yang ${ }^{1}$, Yan Li $^{2}$, \\ Shiqiang $\mathbf{X u}^{1}$ \\ ${ }^{1}$ Department of Gynecologic Oncology, Sichuan Cancer Hospital, Chengdu, Sichuan, People's Republic of China \\ ${ }^{2}$ The First Affiliated Hospital, Nanchang University, Nanchang, People's Republic of China \\ Correspondence to: Shiqiang Xu, email: xu_shiqiang@126.com
}

Keywords: long noncoding RNA, HOTAIR, genetic variants, ovarian cancer

Received: November 22, $2015 \quad$ Accepted: April 19, $2016 \quad$ Published: April 28, 2016

\begin{abstract}
Ovarian cancer is one of the common female malignant tumors globally. However, exactly mechanism of ovarian cancer remained unknown. HOTAIR, a IncRNA in the mammalian HOXC locus, has been fully explored for its genetic variants, expression level and carcinogenesis, development and progression of multiple cancers, except for ovarian cancer. In this study, we hypothesized that abnormal expression of HOTAIR and common variants of HOTAIR are associated with risk of Epithelial ovarian cancer (EOC). We first evaluated the HOTAIR levels in 100 paired tissues of EOC patients and corresponding normal tissues. Results showed that the expression level of HOTAIR in EOC tissues was significantly higher than that in corresponding normal tissues. Then the genotyping analyses of HOTAIR gene was conducted in a Chinese population. The results indicated that rs4759314 and rs7958904 were significantly associated with EOC susceptibility. For rs4759314, the difference between the $\mathbf{G}$ allele (as the reference) and the $A$ allele was statistically significant (adjusted OR, 1.34; 95\% CI: 1.08-1.65; $P=6.8 \times 10^{-3}$ ). For rs7958904, $C$ allele was associated a significantly decreased EOC risk when compared with G allele (OR: $0.77 ; 95 \% \mathrm{CI}: 0.67-0.89 ; P=4.2 \times 10^{-4}$ ). The study identified that HOTAIR variants could be a useful biomarker for the predisposition to EOC and for the early diagnosis of the disease.
\end{abstract}

\section{INTRODUCTION}

Ovarian cancer is the most lethal gynecologic malignancy and the fifth cause of cancer-related deaths among females worldwide [1]. It's reported that there will be totally 21,290 new cases and 14,180 new deaths in United States in 2015 [1]. Epithelial ovarian cancer (EOC) accounts for $90 \%$ to $95 \%$ of all cases of ovarian cancer $[2,3]$. However, the etiology of EOC is not well understood but is likely to involve both genetic and environmental factors [4]. Therefore, discovery of new genes related to EOC risk and survival, as well as understanding their mechanism may provide important clues for, early detection, precise diagnosis and personalized therapy for EOC patients.

Recently, long non-coding RNAs (lncRNAs) have been focused for their wide range of biological regulatory functions. HOTAIR, a lncRNA located in the HOXC locus, has been fully explored for its genetic variants, expression level and carcinogenesis, development and progression of multiple cancers [5-12]. However, The specific role of HOTAIR in EOC susceptibility still remain unknown. Given the genetic variants and expression level of HOTAIR in carcinogenesis, development and progression of multiple cancers $[13,14]$, we hypothesized that common variants of HOTAIR are associated with risk of EOC. We therefore performed genotyping analyses of HOTAIR gene in this study conducted in Chinese population.

\section{RESULTS}

Characteristics of study subjects

The Clinical characteristics of the 1,000 patients with EOC and 1,000 controls are presented in Table 1. The average age of the EOC cases and the healthy 
Table 1: Clinical characteristics of the controls and patients

\begin{tabular}{|c|c|c|c|}
\hline Variables & Patients $(n=1,000)$ & Controls $(n=1,000)$ & $P$-value \\
\hline Age at diagnosis & $65.2 \pm 6.1$ & $64.8 \pm 4.7$ & 0.100 \\
\hline \multicolumn{4}{|c|}{ Family history of cancer } \\
\hline Yes & 99 & 21 & $P<0.001$ \\
\hline No & 901 & 979 & \\
\hline \multicolumn{4}{|l|}{ Smoking status } \\
\hline Never & 877 & 918 & 0.003 \\
\hline Ever & 123 & 82 & \\
\hline \multicolumn{4}{|l|}{ Drinking status } \\
\hline Never & 746 & 793 & 0.766 \\
\hline Ever & 254 & 207 & \\
\hline \multicolumn{4}{|l|}{ Body mass index } \\
\hline$<25 \mathrm{~kg} / \mathrm{m}^{2}$ & 500 & 511 & 0.623 \\
\hline$\geq 25 \mathrm{~kg} / \mathrm{m}^{2}$ & 500 & 489 & \\
\hline
\end{tabular}

controls was 65.2 and 64.8 years, respectively. No significant differences between the controls and cases were detected for age, drinking status or BMI. While significant differences were detected for smoking status and family history of cancer with $P$ values smaller than 0.01 .

\section{Associations of tagSNPs and EOC risk}

The genotype distribution of all three tagSNPs (rs4759314, rs7958904 and rs874945) and their associations with EOC risk are shown in Table 2. The genotype distributions in the three SNPs were consistent with those expected from HWE among healthy controls $(P>0.05)$. For rs 4759314 , the carriers with the genotype AG have a 1.16-fold (95\% CI: 0.90 1.51) risk of EOC and for those with the genotype AA have a 1.85 -fold (95\% CI: 1.11-3.09) risk of EOC, when compared to those with the genotype GG. When analyzed using the additive model, the trend was also significant (adjusted OR, 1.34; 95\% CI: 1.08-1.65; $\left.P=6.8 \times 10^{-3}\right)$. For rs 7958904 , carriers of $\mathrm{C}$ allele have a significantly decreased EOC risk when compared with those of G allele (OR: 0.77 ; $95 \%$ CI: $0.67-0.89$; $\left.P=4.2 \times 10^{-4}\right)$. The adjusted OR for the carriers of genotype CG was 0.84 (95\% CI: $0.70-1.01)$ and 0.53 (95\% CI: 0.37-0.75) for those with the genotype CC, when compared with those of genotype GG. We didn't detected any significant associations for rs874945. The stratified analyses by smoking status, drinking status and BMI were also conducted for rs4759314 and rs7958904 (Table 3). The trend didn't change materially.

\section{Quantitative real-time RT-PCR analyses of HOTAIR}

To confirm the functional relevance and abnormal expression of HOTAIR in EOC patients, we first evaluated the HOTAIR levels in 100 paired tissues of EOC patients and paired normal tissues. The expression level of lncRNA HOTAIR in EOC tissues was significantly higher than that in paired normal tissues (Figure $1, P<0.001$ ).

\section{DISCUSSION}

In current study, we first evaluated the HOTAIR levels in paired tissues of EOC patients and corresponding normal tissues. The expression level of lncRNA HOTAIR in EOC tissues was significantly higher than that in paired normal tissues. We then evaluated three tagSNPs SNPs of HOTAIR gene to investigate whether these SNPs are related to EOC risk in a Chinese Han population. Our results demonstrate that rs4759314 and rs7958904 were significantly associated with EOC susceptibility. To our knowledge, this should be the first study which aims to examine the association between genetic variants of IncRNA HOTAIR and EOC risk in a relatively large group of Asians.

LncRNAs are involved in many human disease, and could drive the development and progression of 
Table 2: Genetic variants of HOTAIR and EOC risk

\begin{tabular}{|c|c|c|c|}
\hline Genotype & Cases & Controls & Adjusted OR (95\% CI)* \\
\hline \multicolumn{4}{|l|}{ rs4759314 } \\
\hline AA & 819 & 852 & 1.00 (reference) \\
\hline $\mathrm{AG}$ & 140 & 125 & $1.16(0.90-1.51)$ \\
\hline GG & 41 & 23 & $1.85(1.11-3.09)$ \\
\hline G vs A & & & $1.34(1.08-1.65)$ \\
\hline$P$ trend & & & $6.8 \times 10^{-3}$ \\
\hline \multicolumn{4}{|l|}{ rs7958904 } \\
\hline GG & 594 & 533 & 1.00 (reference) \\
\hline CG & 355 & 380 & $0.84(0.70-1.01)$ \\
\hline $\mathrm{CC}$ & 51 & 87 & $0.53(0.37-0.75)$ \\
\hline $\mathrm{C}$ vs $\mathrm{G}$ & & & $0.77(0.67-0.89)$ \\
\hline$P$ trend & & & $4.2 \times 10^{-4}$ \\
\hline \multicolumn{4}{|l|}{ rs874945 } \\
\hline GG & 665 & 677 & 1.00 (reference) \\
\hline $\mathrm{AG}$ & 283 & 279 & $1.03(0.85-1.26)$ \\
\hline AA & 52 & 44 & $1.20(0.79-1.82)$ \\
\hline A vs $G$ & & & $1.07(0.91-1.25)$ \\
\hline$P$ trend & & & 0.382 \\
\hline
\end{tabular}

*Asjusting for age at diagnosis, family history of cancer, smoking status, drinking status, and BMI.

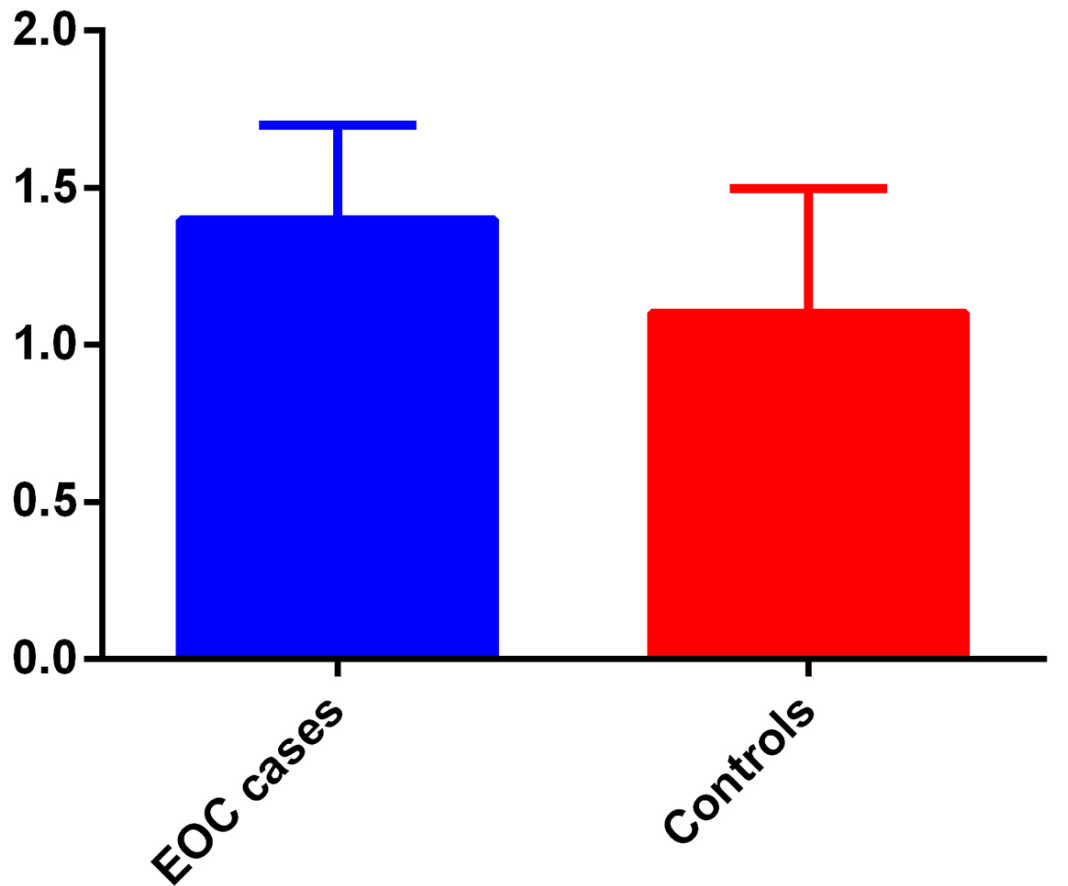

EOC cases

Controls

Figure 1: Quantitative real-time RT-PCR analyses of HOTAIR. 
Table 3: Genetic variants of HOTAIR and EOC risk stratified by co-variables

\begin{tabular}{|c|c|c|}
\hline \multicolumn{3}{|c|}{ Variables } \\
\hline Body mass index & $1.33(1.07-1.65)$ & rs7958904 (C vs G) \\
\hline$\geq 25 \mathrm{~kg} / \mathrm{m}^{2}$ & $\mathbf{0 . 0 1 0}$ & $0.76(0.63-0.91)$ \\
\hline P trend & $1.34(1.07-1.67)$ & $\mathbf{0 . 0 0 3}$ \\
\hline$<25 \mathrm{~kg} / \mathrm{m}^{2}$ & $\mathbf{0 . 0 0 9}$ & $0.79(0.67-0.93)$ \\
\hline P trend & \multicolumn{3}{|c|}{$\mathbf{0 . 0 0 5}$} \\
\hline Smoking status & $1.35(1.08-1.68)$ & $0.76(0.65-0.89)$ \\
\hline Smokers & $\mathbf{0 . 0 0 8}$ & $\mathbf{8 . 2} \times \mathbf{1 0}-\mathbf{4}$ \\
\hline P trend & $1.33(0.85-2.07)$ & $0.78(0.46-1.33)$ \\
\hline Non-smokers & 0.211 & 0.361 \\
\hline P trend & \multicolumn{3}{|c|}{} \\
\hline Drinking status & $1.33(1.07-1.65)$ & $0.76(0.63-0.94)$ \\
\hline Drinkers & $\mathbf{0 . 0 1 0}$ & $\mathbf{0 . 0 0 9}$ \\
\hline P trend & $1.36(0.86-2.15)$ & $0.79(0.54-1.15)$ \\
\hline Non-drinkers & 0.189 & 0.223 \\
\hline P trend & &
\end{tabular}

the diseases [8, 15-23]. The lncRNA HOTAIR could modify the progress of carcinogenesis [7, 12, 20]. HOTAIR (for HOX transcript antisense RNA), was located on chromosome 12: 53.96-53.97 Mb [15]. The gene length of lncRNA HOTAIR gene was $6,232 \mathrm{bp}$. Loss of HOTAIR could restrain invasiveness of cancers [12]. Finally, through these approach, HOTAIR gene could regulate the progress of carcinogenesis and its development.

In current study, we detected significant associations between the rs4759314 and rs7958904 and EOC susceptibility among Chinese population, some studies have also demonstrated significant associations between rs7958904 and decreased risk of colorectal cancer [7], rs 4759314 with the increased gastric cancer risk [20]. The major strength of this study is the use of a large sample size to study genetic predispositions, which are less likely to be affected by confounding factors. Another strength is our sufficient demographic information. In summary, the present study showed significant associations between HOTAIR rs4759314 and rs7958904 and the risk of EOC.

\section{MATERIALS AND METHODS}

\section{Subjects}

Included in this study were 1,000 continuous subjects diagnosed with EOC through a rapid caseascertainment system that were diagnosed from 2010 to 2015, and 1,000 controls were identified and frequency matched by 5 -year age groups and resident regions. A histopathological diagnosis was made by an experienced pathologist. Blood samples $(10 \mathrm{ml})$ were obtained from the subjects who participated in the study. Clinical information of patients were collected from medical records, and a structured questionnaire was used to elicit detailed information on demographic factors. All specimens were handled and made anonymous according to the ethical and legal standards. Approval was granted from relevant review boards, and informed consent was granted by all included participants.

\section{SNP selection and genotyping}

Using data of HapMap Chinese Han Beijing (CHB), we selected the tagSNPs capturing all the common SNPs (minor allele frequency, MAF $>0.05$ ) located in the chromosome locus transcribed into HOTAIR and its flanking 2000bp region with $r^{2}>0.8$. Finally, three SNPs were selected for genotyping (rs4759314, rs7958904 and rs874945). Genomic DNA was extracted from peripheral blood leukocytes using the GoldMag ${ }^{\circledR}$ nanoparticles method (GoldMag Ltd. Xi'an, China) according to the manufacturer's instructions, and DNA concentration was measured using the NanoDrop 2000 (Thermo Scientific, Waltham, Massachusetts, USA). Sequenom MassARRAY Assay Design 3.0 Software was used to design Multiplexed SNP MassEXTEND assays. SNP genotyping was performed by the Sequenom MassARRAY RS1000 while Sequenom Typer 4.0 Software was used to perform data management and analysis. 


\section{Quantitative real-time RT-PCR analyses of HOTAIR}

The expression of HOTAIR from 100 EOC tissues and adjacent normal tissues were determined by SYBR Green Assay and the levels were normalized by $\beta$-actin by the $2-\Delta \mathrm{Ct}$ method. All assays were conducted by using the ABI 7900 HT real-time PCR system (Applied Biosystems, Foster City, CA, USA).

\section{Statistical analyses}

Differences in the distribution of selected demographic variables and genotypes of tagSNPs were evaluated by Pearson's $\chi^{2}$ test. Hardy-Weinberg equilibrium (HWE) for each SNP among controls was tested using a goodness-of-fit $\chi^{2}$-test. The associations of each SNP and EOC susceptibility were estimated by using unconditional logistic regression analyses with odds ratios (ORs) and 95\% confidence intervals (CIs). Statistical analysis was conducted using the SPSS 19.0 for Windows (SPSS Inc., Chicago, IL, USA). All $p$ values presented in this study are two-sided, and we used $p<0.05$ as the threshold of statistical significance.

\section{CONFLICTS OF INTEREST}

The authors declare that they have no conflicts of interest.

\section{REFERENCES}

1. Siegel RL, Miller KD, Jemal A. Cancer statistics, 2015. CA Cancer J Clin. 2015; 65:5-29.

2. Nagaraj AB, Joseph P, Kovalenko O, Singh S, Armstrong A, Redline R, Resnick K, Zanotti K, Waggoner $\mathrm{S}$, DiFeo A. Critical role of wnt/beta-catenin signaling in driving epithelial ovarian cancer platinum resistance. Oncotarget. 2015; 6:23720-23734. doi: 10.18632/ oncotarget. 4690 .

3. Auer K, Bachmayr-Heyda A, Aust S, Sukhbaatar N, Reiner AT, Grimm C, Horvat R, Zeillinger R, Pils D. Peritoneal tumor spread in serous ovarian cancer-epithelial mesenchymal status and outcome. Oncotarget. 2015; 6:17261-17275. doi: 10.18632/oncotarget.3746.

4. Haruta S, Furukawa N, Yoshizawa Y, Tsunemi T, Nagai A, Kawaguchi R, Tanase Y, Yoshida S, Kobayashi H. Molecular genetics and epidemiology of epithelial ovarian cancer (review). Oncol Rep. 2011; 26:1347-1356.

5. Zhou C, Ye L, Jiang C, Bai J, Chi Y, Zhang H. Long noncoding rna hotair, a hypoxia-inducible factor-1alpha activated driver of malignancy, enhances hypoxic cancer cell proliferation, migration, and invasion in non-small cell lung cancer. Tumour Biol. 2015; 36:9179-88.
6. Jing L, Yuan W, Ruofan D, Jinjin Y, Haifeng Q. Hotair enhanced aggressive biological behaviors and induced radio-resistance via inhibiting p21 in cervical cancer. Tumour Biol. 2015; 36:3611-3619.

7. Xue Y, Gu D, Ma G, Zhu L, Hua Q, Chu H, Tong N, Chen J, Zhang Z, Wang M. Genetic variants in lncrna hotair are associated with risk of colorectal cancer. Mutagenesis 2015; 30:303-310.

8. Yan TH, Lu SW, Huang YQ, Que GB, Chen JH, Chen YP, Zhang HB, Liang XL, Jiang JH. Upregulation of the long noncoding rna hotair predicts recurrence in stage ta/t1 bladder cancer. Tumour Biol. 2014; 35:10249-10257.

9. Huang L, Liao LM, Liu AW, Wu JB, Cheng XL, Lin JX, Zheng M. Overexpression of long noncoding rna hotair predicts a poor prognosis in patients with cervical cancer. Arch Gynecol Obstet. 2014; 290:717-723.

10. Lu L, Zhu G, Zhang C, Deng Q, Katsaros D, Mayne ST, Risch HA, Mu L, Canuto EM, Gregori G, Benedetto C, Yu H. Association of large noncoding rna hotair expression and its downstream intergenic cpg island methylation with survival in breast cancer. Breast Cancer Res Treat. 2012; 136:875-883.

11. Kim K, Jutooru I, Chadalapaka G, Johnson G, Frank J, Burghardt R, Kim S, Safe S. Hotair is a negative prognostic factor and exhibits pro-oncogenic activity in pancreatic cancer. Oncogene. 2013; 32:1616-1625.

12. Gupta RA, Shah N, Wang KC, Kim J, Horlings HM, Wong DJ, Tsai MC, Hung T, Argani P, Rinn JL, Wang Y, Brzoska P, Kong B, et al. Long non-coding rna hotair reprograms chromatin state to promote cancer metastasis. Nature. 2010; 464:1071-1076.

13. Wan Y, Chang HY: Hotair. Flight of noncoding rnas in cancer metastasis. Cell Cycle. 2010; 9:3391-3392.

14. Niinuma T, Suzuki H, Nojima M, Nosho K, Yamamoto H, Takamaru H, Yamamoto E, Maruyama R, Nobuoka T, Miyazaki Y, Nishida T, Bamba T, Kanda T, et al. Upregulation of mir-196a and hotair drive malignant character in gastrointestinal stromal tumors. Cancer Res 2012; 72:1126-1136.

15. Cai B, Song XQ, Cai JP, Zhang S. Hotair: A cancer-related long non-coding rna. Neoplasma. 2014; 61:379-391.

16. Loewen G, Jayawickramarajah J, Zhuo Y, Shan B. Functions of lncrna hotair in lung cancer. J Hematol Oncol. 2014; 7:90.

17. Loewen G, Zhuo Y, Zhuang Y, Jayawickramarajah J, Shan B. Lincrna hotair as a novel promoter of cancer progression. J Cancer Res Updat. 2014; 3:134-140.

18. Wu Y, Zhang L, Wang Y, Li H, Ren X, Wei F, Yu W, Wang $\mathrm{X}, \mathrm{Yu} \mathrm{J}$, Hao $\mathrm{X}$. Long noncoding rna hotair involvement in cancer. Tumour Biol. 2014; 35:9531-9538.

19. Zhuang Y, Nguyen HT, Burow ME, Zhuo Y, El-Dahr SS, Yao X, Cao S, Flemington EK, Nephew KP, Fang F, CollinsBurow B, Rhodes LV, Yu Q, et al. Elevated expression of long intergenic non-coding rna hotair in a basal-like variant of mcf-7 breast cancer cells. Mol Carcinog. 2015; 54:1656-67. 
20. Du M, Wang W, Jin H, Wang Q, Ge Y, Lu J, Ma G, Chu H, Tong N, Zhu H, Wang M, Qiang F, Zhang Z. The association analysis of lncrna hotair genetic variants and gastric cancer risk in a chinese population. Oncotarget. 2015; 6:31255-62. doi: 10.18632/oncotarget.5158.

21. Li L, Dang Q, Xie H, Yang Z, He D, Liang L, Song W, Yeh S, Chang C. Infiltrating mast cells enhance prostate cancer invasion via altering lncrna-hotair/prc2-androgen receptor (ar)-mmp9 signals and increased stem/progenitor cell population. Oncotarget. 2015; 6:14179-14190. doi: 10.18632/oncotarget.3651
22. Sharma S, Mandal P, Sadhukhan T, Roy Chowdhury R, Ranjan Mondal N, Chakravarty B, Chatterjee T, Roy S, Sengupta S. Bridging links between long noncoding rna hotair and hpv oncoprotein e7 in cervical cancer pathogenesis. Sci Rep. 2015; 5:11724.

23. Wang YL, Overstreet AM, Chen MS, Wang J, Zhao HJ, Ho PC, Smith M, Wang SC. Combined inhibition of egfr and c-abl suppresses the growth of triple-negative breast cancer growth through inhibition of hotair. Oncotarget. 2015; 6:11150-11161. doi: 10.18632/oncotarget.3441 